\title{
Treatment of Wastewater Containing Hexavalent Chromium Using Zeolite Ceramic Adsorbent in Adsorption Column
}

\author{
Tuty Emilia Agustina", Tine Aprianti ${ }^{\#}$, Siti Miskah $^{\#}$ \\ \# Chemical Engineering Department, Universitas Sriwijaya, \\ Jl. Palembang-Prabumulih KM 32 Inderalaya, Ogan Ilir, South Sumatera, 30662, Indonesia \\ E-mail: tuty_agustina@unsri.ac.id,tine.aprianti@gmail.com,miskah56@yahoo.com
}

\begin{abstract}
Natural Zeolites in powdered form have commonly used as adsorbent and one of the most crucial compound in water treatment plant, in filter system of petrochemicals or other processes under environmentally, physically and chemically conditions. But in the form of powder, zeolites are easily washed out in liquid or gas stream. Therefore, a modification would be necessary to solve this problem. Zeolites and clay were modified into ceramic adsorbent to adsorb heavy metal pollutant that is hexavalent chromium $\mathrm{Cr}$ (VI) contained in electroplating industrial effluents. Zeolite and clay were mixed evenly and molded into small balls

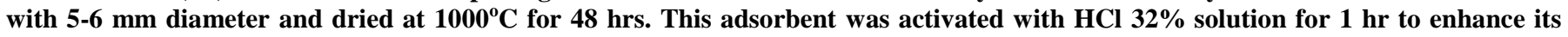
adsorption potential. Ten samples with various ratios of zeolite:clay $(3: 37-12: 28)$ with the total adsorbent mass of $1000 \mathrm{~g}$ was examined. $\mathrm{Cr}$ (VI) uptake in liquid wastewater was studied by varying contact time and the ratio of zeolite and clay. The effect of activation treatment with $\mathrm{HCl} 32 \%$ solution on adsorption performance of zeolite ceramic adsorbent was also investigated. Analysis of wastewater output indicates a reduction of hexavalent chromium concentration reaches $99.45 \%$ at contact time $10 \mathrm{~h}$ with $12: 28$ ratio of activated adsorbent. This shown that the process of adsorption had greatly reduced the contamination of $\mathrm{Cr}$ (VI) and may have been a solution for environment problem regarding wastewater containing $\mathrm{Cr}$ (VI).
\end{abstract}

Keywords — hexavalent chromium; heavy metal; zeolite ceramic; adsorbent; adsorption

\section{INTRODUCTION}

Due to its wide availability, minerals such as zeolites is easily found in many resources all over the world. They have cavities among them containing aluminosilicate which forms tetrahedrons. They have become important in the industrial world mostly as the molecular sieve, ion exchangers, shield against high-energy radiation, and other industrial processes as the result of its inert structure, microporous and high ability in ion exchange process. Therefore, studies about their structures, ion exchange and adsorption-desorption properties have been widely conducted [1]-[5].

The crystalline aluminosilicate molecular sieves of zeolites have special structures. These compounds are comprised of a three-dimensional network of silicon and aluminum oxide tetrahedrons $\left(\mathrm{SiO}_{4}\right.$ and $\left.\mathrm{AlO}_{4}^{-}\right)$bound by shared oxygen atoms with abundant charge-compensating cations. As a result, the structures form porous networks with micropores in the range of $\sim 2-10 \AA$ [6]. Zeolites also have enormous surface areas due to their microporosity and containing variable acidic properties, but it depends on the composition. Regarding these special properties, they can be utilized in wide range applications such as ion exchange, adsorption, catalysis and membrane separation [7].
The environment aspect of a natural zeolite location may identify its characteristics: seasonal and daily differential temperature, geographic and soil materials causing differences of its composition, e.g., the amounts of impurities in the lattice, structural deformation, etc., and because of that, the zeolite usually has unique property or composition depends on its environment [8]. Zeolite is one of the most important material in water treatment plant, in filter system of petrochemicals or other similar structure under environmental, physical and chemical conditions.

Industrial waste discharge is one of the major problems that may endanger environment by causing hazardous pollutants such as heavy metals. Heavy metals pollutants are not easily degradable, toxic and carcinogenic; its exposure is a serious threat to the environment [9], and raising health problems. In addition, heavy metals can not be completely removed using conventional treatment processes such as biological treatment with activated sludge and anaerobic digestion or using light and other moderate oxidative agents.

The waste water discharges from industries such as electroplating, leather, and textile mainly contains a large amount of trivalent $\mathrm{Cr}$ (III) and hexavalent chromium $\mathrm{Cr}$ (VI) ions which hazardous to the environment. Of these, the $\mathrm{Cr}$ (VI) is mutagenic and toxic [10],[11]. It is also poisonous to 
bacteria, and other living organisms. Recently, a large number of efforts have been applied to develop costeffective technology to remove the heavy metal ions from wastewater, such as photodegradation, adsorption, and membrane separation technologies [12]. Among those, adsorption is seen as a more well-known because of its practical operation, removal efficacy easily regenerated adsorbent, low-cost, and not easily polluted by secondary pollutants. Activated carbon, chitosan, zeolites, etc., as porous adsorbents were currently examined due to their enormously wide surface area [12]-[15]. In general, the zeolite is only available as a fine powder or granular powder. And their use in the form of powder is limited by high head loss, difficulty in separation of the solid from solution. In order to overcome these shortcomings, modification of zeolite leads to the formation of the adsorbent with special properties for heavy metal adsorption removal from aqueous solutions.

Clay has been known as the cheap adsorbent in aqueous pollutant uptakes such as metallic ions, bacteria and other organic pollutants due to its high availability, cost-effective and good quality in adsorption [16]-[18]. Clay is a great adsorbent because of its large surface area specifically, with chemical and mechanical stability, layered structure, and high cation exchange capacity [18], [19]. On the contrary, raw clay expresses insufficient adsorption capacity of some anionic pollutants because of its abundant negative charges on its surface area [20]. For example, clay minerals such as kaolinite, montmorillonite, and illite may adsorb arsenate in the range of 0.15 to $8.4 \mu \mathrm{mol} / \mathrm{g}$, which is incomparable with iron-containing minerals such as ferrihydrite and goethite, it may adsorb arsenate in the range about $200 \mu \mathrm{mol} / \mathrm{g}$ to 700 $\mu \mathrm{mol} / \mathrm{g}$ [21]. Thus, we can modify or mix clay with other metal ions like irons to enhance its adsorption capacity [22], [23].

However, zeolite modification such as oxide coated zeolite, and iron oxide coated zeolite have been used to remove $\mathrm{Fe}^{2+}$ from an aqueous solution. The results indicated that Manganese oxide coated zeolite has a good ability $(80 \%$ removal of $\mathrm{Fe}^{2+}$ ) for the removal of $\mathrm{Fe}$ from water [24]. In this study, zeolite and clay were modified into ceramic adsorbent in order to increase the physical properties of adsorbent.

The aim of this research was to identify the $\mathrm{Cr}$ (VI) adsorption capacity of zeolite mixed with clay and the modification of those into ceramic adsorbent with respect to ten different ratios of zeolite and clay, contact time, and the effect of activation to the adsorbent. The $\mathrm{Cr}$ (VI) adsorption capacity of zeolite ceramic adsorbent was studied under batch experiments. A simple preparation of the zeolite ceramic was performed with $\mathrm{HCl} 32 \%$ solution.

\section{MATERIAL AND METHOD}

\section{A. Material Preparation}

Natural clay in this study was collected from the Westsouthern part of Indonesia (Musi Banyuasin District, South Sumatera Province). It was cleaned with deionized water, dried at $100^{\circ} \mathrm{C}$ for $1 \mathrm{~h}$, crushed with mortar to achieve the required particle size less than $75 \mu \mathrm{m}$. After drying, the clean clay with the right particle size was kept in a dry and clean container for further process.

Ten samples of adsorbents used were prepared by varying the ratio amount of zeolite:clay $(3: 37,4: 36,5: 35,6: 34,7: 33$, $8: 32,9: 31,10: 30,11: 29,12: 28$ ) with total mass adsorbent of $1000 \mathrm{~g}$.

First, the powdered zeolite and clay were mixed and stirred until zeolite was evenly mixed with clay, add enough deionized water to the mixtures and mold into small balls approximately 5-6 mm diameter. Afterward, these balls were dried at $1000^{\circ} \mathrm{C}$ for $48 \mathrm{hrs}$. Finally, the small balls had become ceramics and were ready for use.

\section{B. Zeolite Ceramic Activation}

It has been acknowledged that the pore system becomes blocked with increasing impurities contained in pore system. It prevents the build-up reactions inside the pores so that the activation treatment should be conducted.

Zeolite ceramic balls were soaked with $\mathrm{HCl} 32 \%$ for $1 \mathrm{~h}$ to remove coke deposits inside the pores. After that, the deionized water was used to wash the zeolite ceramic. Finally, the zeolite ceramic was dried at $150^{\circ} \mathrm{C}$ in an oven for $1 \mathrm{~h}$.

On the adsorption process, the load of optimum adsorbent examined was $700 \mathrm{~g} / 500 \mathrm{ml}$. The various ratio between zeolite and clay (3:37-12:29) and contact time (1- $10 \mathrm{~h})$ to examine the effect of activated zeolite ceramic on the uptake of hexavalent chromium. Further experiments between activated and non-activated zeolite ceramic on the ratio $(4: 36$, $6: 34,8: 32,10: 30,12: 28)$ to expose the effect of activation on zeolite ceramic adsorbent. The contacts between adsorbent and adsorbate were conducted in a glass column with $50 \mathrm{~cm}$ height and $5.08 \mathrm{~cm}$ diameter. The feed was pumped with $21 \mathrm{~min}^{-1}$ flow rate from a feed container, flow it to the top of the column using a small tube.

The concentration analysis of hexavalent chromium of liquid samples before and after treatment with adsorbent was carried out by atomic absorption spectrometry (AAS). Adsorption capacity was calculated by the equation:

$$
\mathrm{q}=\frac{\left(\mathrm{C}_{\mathrm{o}}-\mathrm{C}_{\mathrm{t}}\right) V}{W}
$$

and the percentage of adsorption is measured by the equation:

$$
\% \text { removal }=\frac{\left(\mathrm{C}_{\mathrm{o}}-\mathrm{C}_{\mathrm{t}}\right)}{\mathrm{C}_{\mathrm{o}}} \times 100 \%
$$

where $\mathrm{q}$ is the adsorption capacity $\left(\mathrm{mg} \mathrm{g}^{-1}\right), \mathrm{C}_{\mathrm{o}}$ and $\mathrm{C}_{\mathrm{t}}$ are the initial and equilibrium concentration of hexavalent chromium in the testing solution $\left(\mathrm{mg} \mathrm{L}^{-1}\right) . V$ is the testing solution's volume (L), and $W$ is the adsorbent's weight $(\mathrm{g})$.

\section{RESULTS AND DISCUSSION}

Fig. 1 shows the adsorption capacity on each zeolite:clay ratios, respectively. The effect of zeolite:clay ratio of adsorption capacity had been crucial, the increase of adsorption capacity is from $34 \mathrm{mg} \mathrm{g}^{-1}$ to $532.74 \mathrm{mg} \mathrm{g}^{-1}$ on increasing the zeolite ratio from 3 to 12 . The addition of zeolite mass contributes fairly in adsorption capacity due to its porous adsorbent and is one of the best compared to the commonly used adsorbent materials for the $\mathrm{Cr}$ (VI) uptake. 
By adding zeolite mass in the ratio of adsorbent had increased the adsorption capacity on $\mathrm{Cr}$ (VI) enormously. $\mathrm{Cr}$ (VI) removal percentage also increase with increasing zeolite to clay ratio as can be seen in Table 1 .

The residual concentrations of Cr (VI) were analyzed by Atomic Absorption Spectrophotometer (AAS), in addition, $\mathrm{Cr}$ (VI) at which species were tested only in the form on chromate anions.

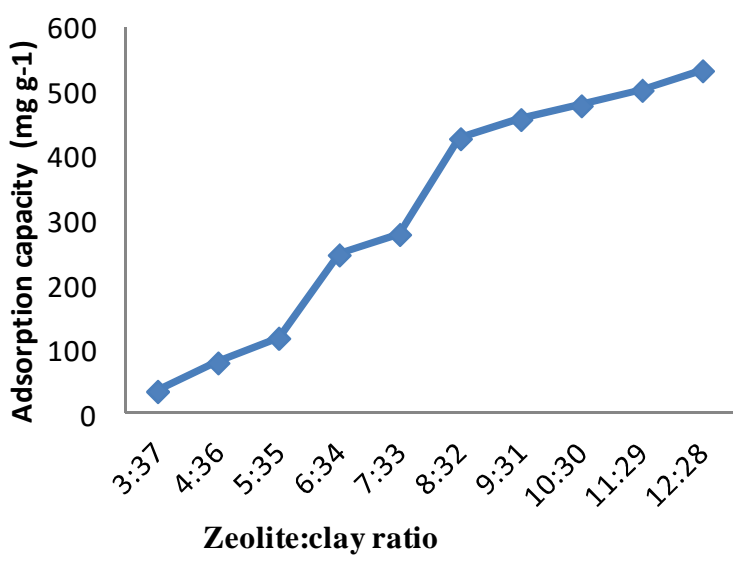

Fig. 1 Variation of zeolite:clay ratio with $8 \mathrm{~h}$ contact time

TABLE I

Cr (VI) Removal Percentage on Various Zeolite:Clay Ratio

\begin{tabular}{|c|c|c|}
\hline $\begin{array}{c}\text { Zeolite:clay } \\
\text { ratio }\end{array}$ & $\begin{array}{c}\text { Sample Cr }(\mathbf{V I}) \\
\text { Concentration }\left(\mathbf{m g ~ L}^{-\mathbf{1}}\right)\end{array}$ & $\begin{array}{c}\text { Cr (VI) removal } \\
(\boldsymbol{\%})\end{array}$ \\
\hline $0: 0$ & 752.10 & 0 \\
\hline $3: 37$ & 704.50 & 6.33 \\
\hline $4: 36$ & 642.24 & 14.61 \\
\hline $5: 35$ & 588.45 & 21.76 \\
\hline $6: 34$ & 407.00 & 45.88 \\
\hline $7: 33$ & 362.55 & 51.79 \\
\hline $8: 32$ & 154.54 & 79.45 \\
\hline $9: 31$ & 112.73 & 85.01 \\
\hline $10: 30$ & 82.30 & 89.00 \\
\hline $11: 29$ & 48.60 & 93.54 \\
\hline $12: 28$ & 6.27 & 99.17 \\
\hline
\end{tabular}

As hoped, these adsorbent ratios were chosen based on their chemical and physical properties which can greatly effect $\mathrm{Cr}$ (VI) capture ability of the resulting adsorbent. The higher zeolite mass in the adsorbent material is causing higher $\mathrm{Cr}(\mathrm{VI})$ removal from $34 \mathrm{mg} \mathrm{g}^{-1}$ (3:37 ratio) to $532.74 \mathrm{mg} \mathrm{g}^{-1}$ (12:28 ratio). It proves that the characteristic of adsorbent materials affects the pore characteristics since they are the main constituent of the pore structures. The size of the pores is determined by the materials added to the adsorbent which also has a huge role in determining the surface area and total pore volume of the material. Generally, high level of porosity is provided by longer molecules [25]. Further surface functionalization of the structure is required to enhance adsorption. It was studied that $\mathrm{Cr}(\mathrm{VI})$ adsorption is directly related to the surface area of the material. However, large pores could increase adsorption and for the highest capture performance.

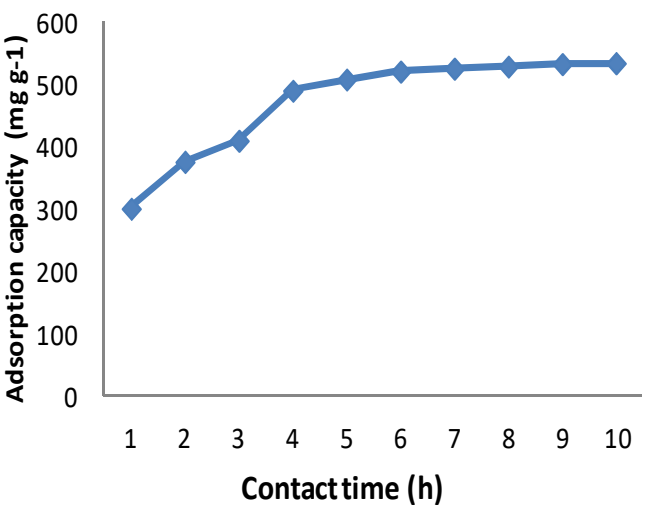

Fig. 2 Variation of contact time for $\mathrm{Cr}$ (VI) removal with zeolite:clay ratio $12: 28$

TABLE II

CR (Vi) Removal Percentage Using Zeolite Ceramic Adsorbent (12: 28 RATIO) ON VARIOUS CONTACT TIME

\begin{tabular}{|c|c|c|}
\hline $\begin{array}{c}\text { Contact time } \\
\text { (h) }\end{array}$ & $\begin{array}{c}\text { Sample Cr }(\mathrm{VI}) \\
\text { Concenration }\left(\mathrm{mg} \mathrm{L}^{-1}\right)\end{array}$ & $\begin{array}{c}\mathrm{Cr}(\mathrm{VI}) \\
\text { removal } \\
(\%)\end{array}$ \\
\hline 0 & 752.10 & 0 \\
\hline 1 & 332.40 & 55.81 \\
\hline 2 & 226.46 & 69.89 \\
\hline 3 & 178.77 & 76.23 \\
\hline 4 & 66.62 & 91.14 \\
\hline 5 & 41.10 & 94.54 \\
\hline 6 & 23.20 & 96.92 \\
\hline 7 & 16.89 & 97.75 \\
\hline 8 & 11.72 & 98.44 \\
\hline 9 & 6.12 & 99.19 \\
\hline 10 & 4.16 & 99.45 \\
\hline
\end{tabular}

The effect of contact time on the adsorption capacity performance and $\mathrm{Cr}(\mathrm{VI})$ removal percentage has also been observed. The results can be shown in Fig. 2 and Table 2. The adsorption capacity rises from $299.79 \mathrm{mg} \mathrm{g}^{-1}$ to 534.24 $\mathrm{mg} \mathrm{g}^{-1}$, respectively. The values are slightly comparable with the previous experimental highest results $532.74 \mathrm{mg} \mathrm{g}^{-1}$. By deriving the relationship between the adsorption ability and contact time, we can acknowledge that the longer contact times, the higher adsorption capacity. The longer contact time has given enough access for the adsorbent surface to make contact and to bind more $\mathrm{Cr}$ (VI) and to make binding sites on the adsorbent surface. The highest $\mathrm{Cr}(\mathrm{VI})$ removal percentage of $99.45 \%$ was achieved at $10 \mathrm{~h}$ of contact time.

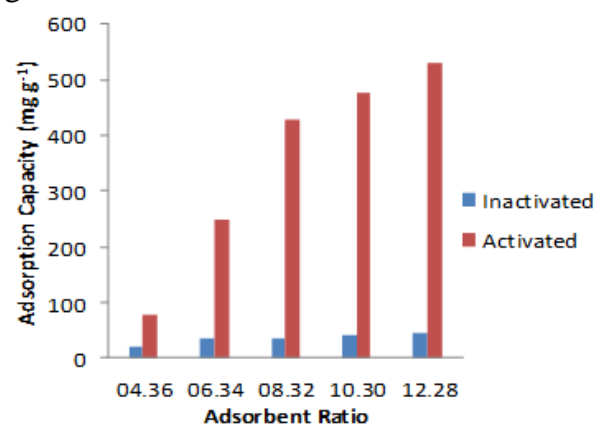

Fig. 3 The effect of activation mechanism on adsorption capacity 
TABLE III

The EFfect of Activation Mechanism on Removal Percentage

\begin{tabular}{|c|c|c|}
\hline \multirow{2}{*}{$\begin{array}{c}\text { Adsorben } \\
\text { t Ratio }\end{array}$} & \multicolumn{2}{|c|}{ Removal percentage } \\
\cline { 2 - 3 } & $\begin{array}{c}\text { Inactivated } \\
(\boldsymbol{\%})\end{array}$ & $\begin{array}{c}\text { Activated } \\
(\boldsymbol{\%})\end{array}$ \\
\hline $4: 36$ & 4.08 & 14.55 \\
\hline $6: 34$ & 6.53 & 46.54 \\
\hline $8: 32$ & 6.93 & 79.80 \\
\hline $10: 32$ & 8.24 & 88.57 \\
\hline $12: 28$ & 8.26 & 99.09 \\
\hline
\end{tabular}

The data in Fig. 3 and Table 3 showed that adsorption capacity and $\mathrm{Cr}(\mathrm{VI})$ removal percentage were significantly increased after activation. The result indicates that pore walls of adsorbent had been widened and clog free during the activation process resulting in the formation of new pores or converting to wider pores. Besides, low adsorption conducted by raw clay due to some anionic pollutants causing abundant negative charges on its surface [20]. These reasons are suitable for our activation purpose. The superior of activated adsorbent compare to inactivated one in oil purification by using bentonite was also reported [26].

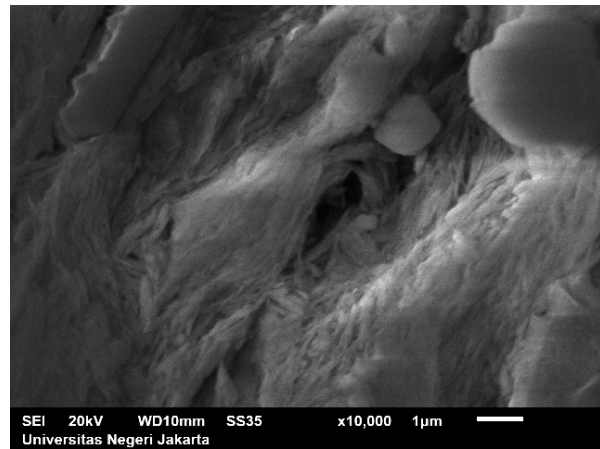

(a)

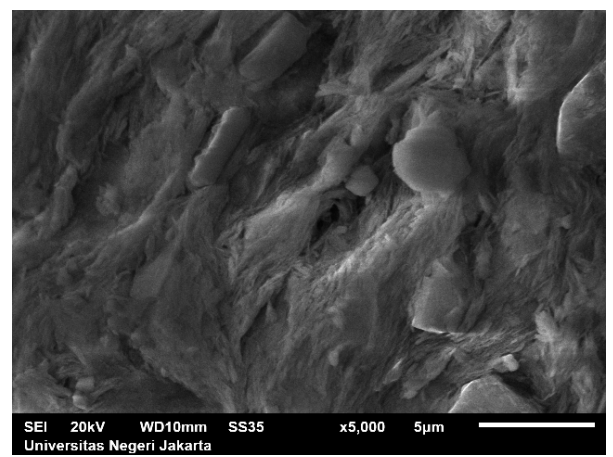

(b)

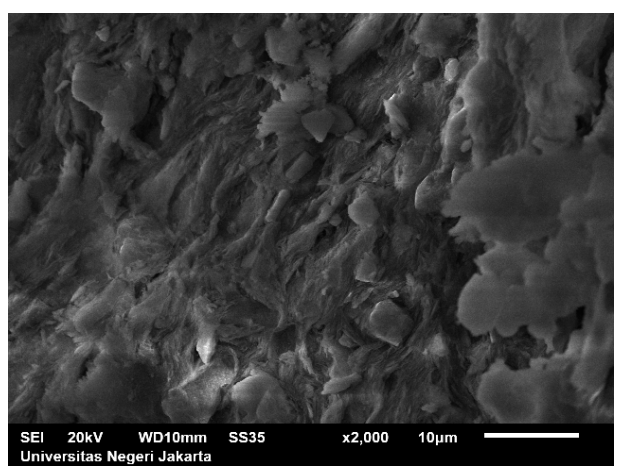

(c)

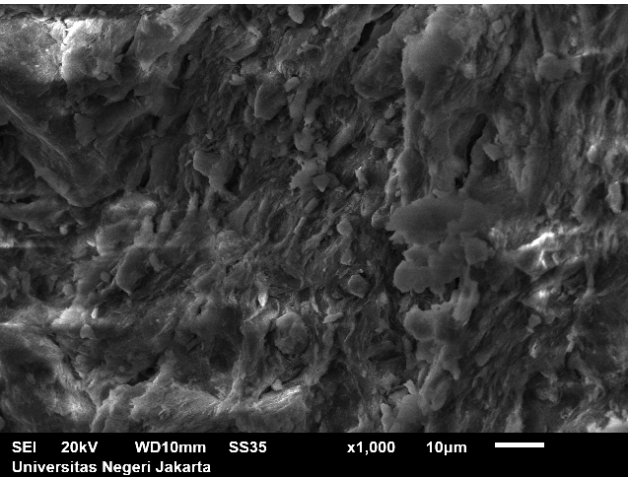

(d)

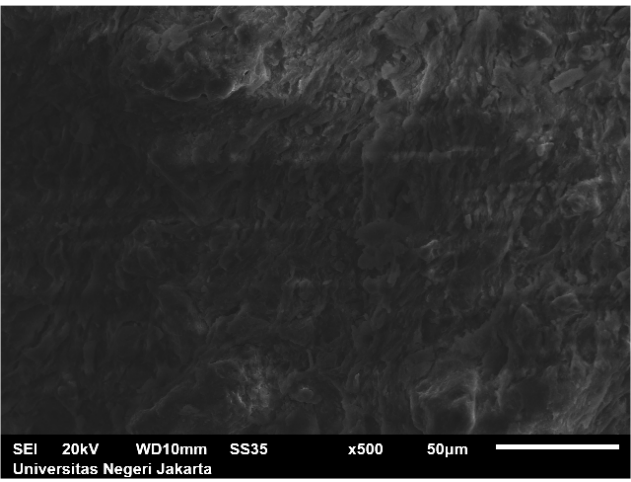

(e)

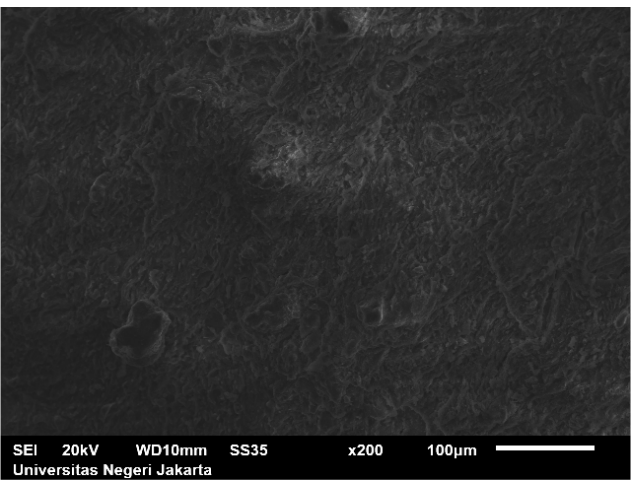

(f)

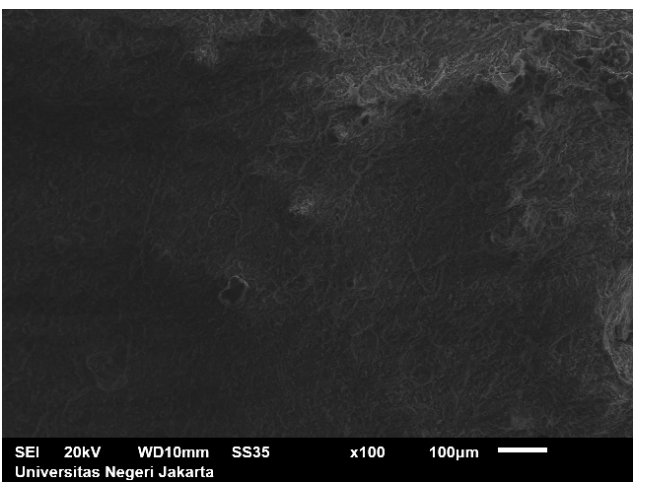

(g)

Fig. 4 (a-g) Surface morphology of adsorbents before activation mechanism by $100-10,000$ times of magnification 


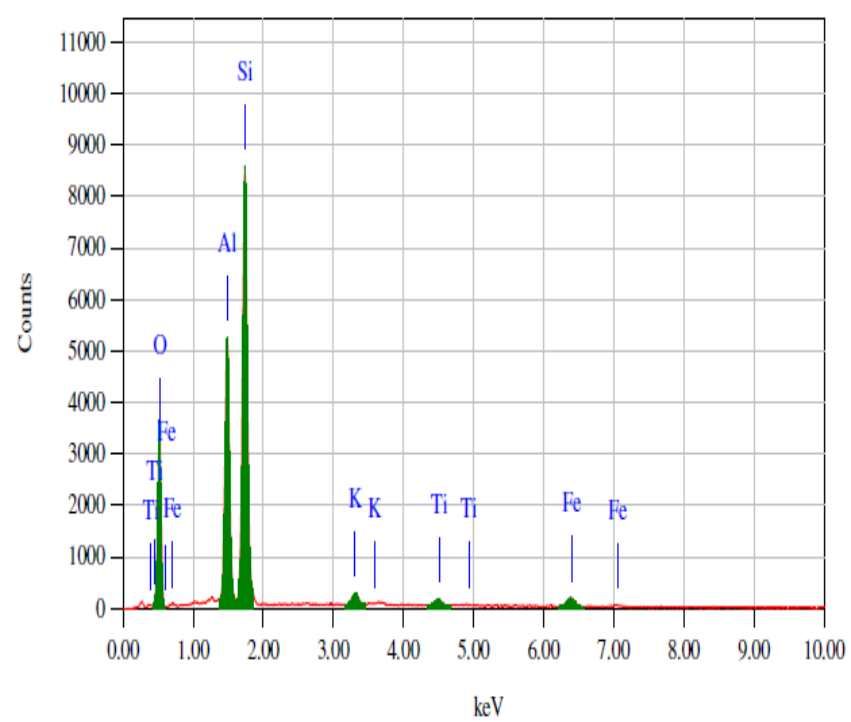

Fig. 5 Adsorbent elements analysis before activation mechanism

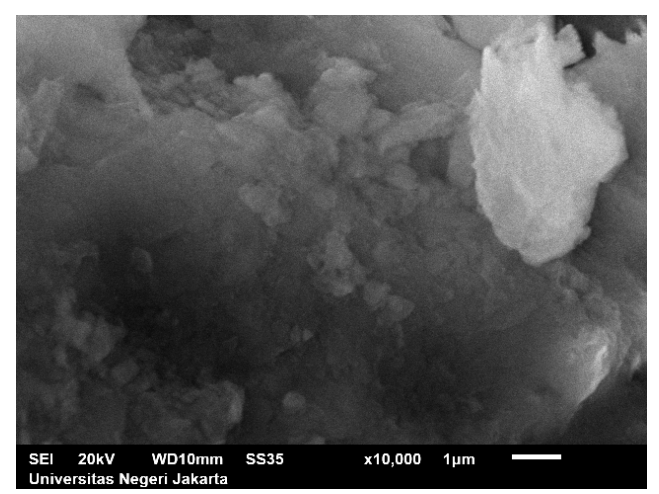

(a)

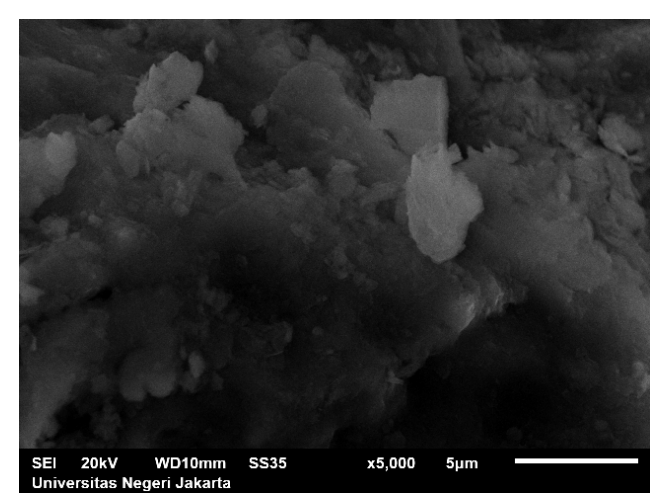

(b)

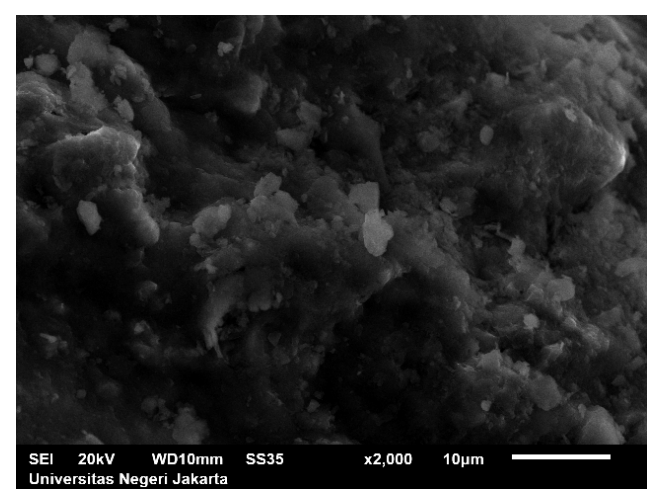

(c)

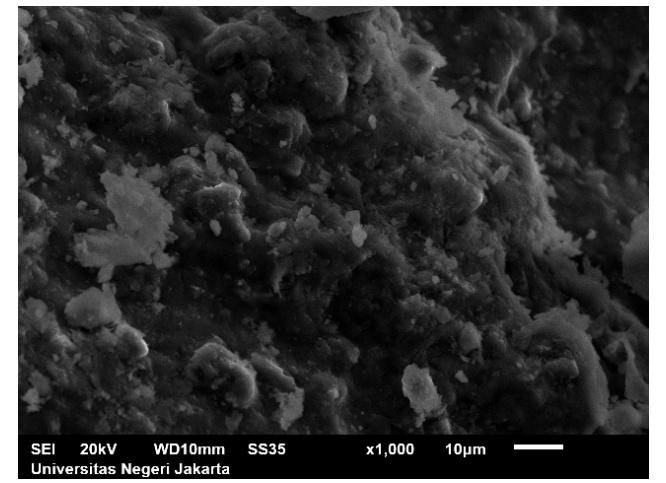

(d)

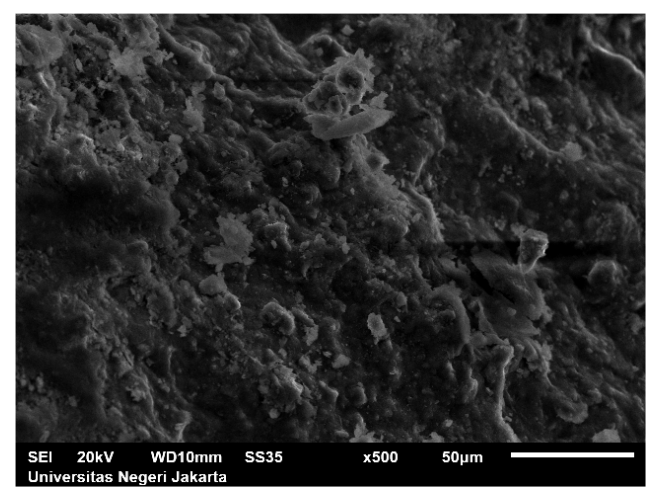

(e)

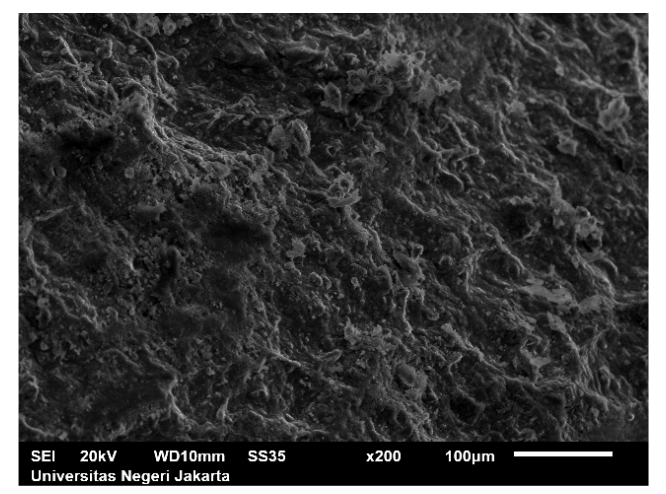

(f)

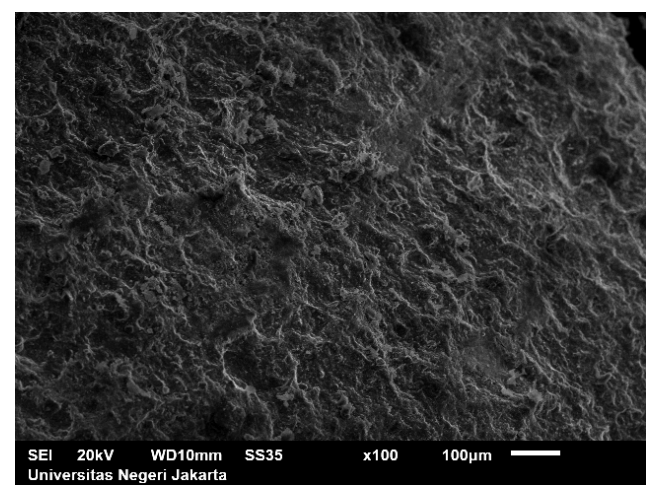

(g)

Fig. 6 (a-g) Surface morphology of adsorbents after activation mechanism by $100-10,000$ times of magnification 
After the activation stage, the surface area has risen its adsorption area sharply, by comparing images shown in Fig. 4 (a-g) and Fig. 6 (a-g) clearly seen that the surface pores become exposed with the oxidation resulting increase in specific surface area and adding micropore volume.

Activation mechanism also contributes in changing the elements composition of the adsorbent, images in Fig. 5 and Fig. 7 are compared to acknowledge that the amount of some elements have seemingly changed after the activation process.

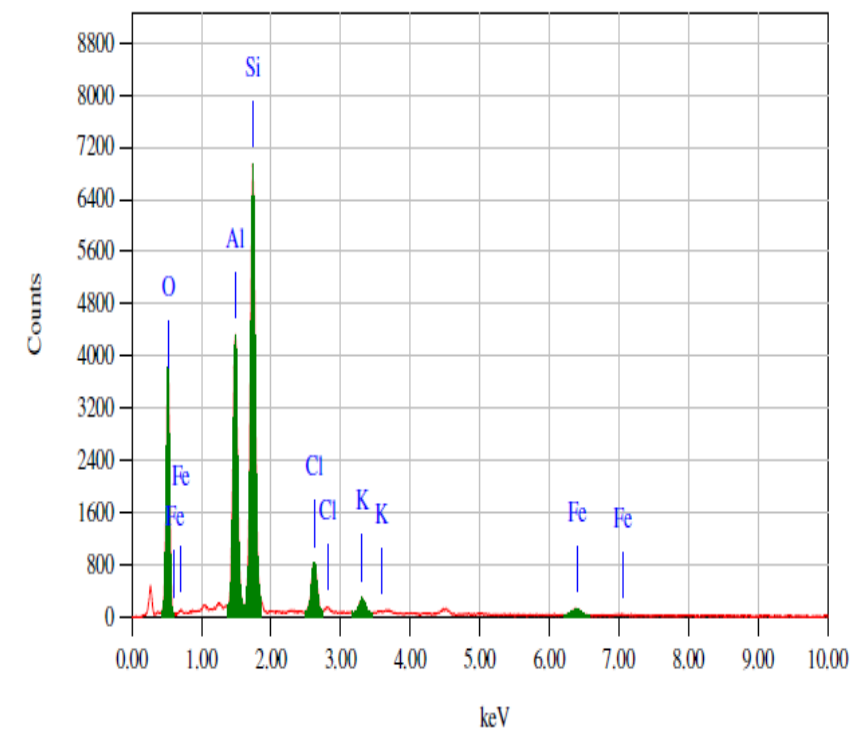

Fig. 7 Adsorbents elements analysis after activation mechanism

\section{CONCLUSION}

Adsorbent ratios between zeolite and clay as the adsorbent material have given chemical and physical properties that may have highly effect $\mathrm{Cr}$ (VI) capture ability of the resulting adsorbent. The higher zeolite mass in the adsorbent material is causing higher $\mathrm{Cr}$ (VI) adsorption capacity from $34 \mathrm{mg} \mathrm{g}^{-1}$ (3:37 ratio) to $532.74 \mathrm{mg} \mathrm{g}^{-1}$ (12:28 ratio). It is assumed that the characteristic of adsorbent materials affects the pore characteristics since they are the main constituent of the pore structures.

The effect of contact time on the adsorption capacity has also been studied where it increases from $299.79 \mathrm{mg} \mathrm{g}^{-1}(1 \mathrm{~h}$ contact time) to $534.24 \mathrm{mg} \mathrm{g}^{-1}$ (10 h contact time), respectively. Further investigations should explore whether a higher adsorption capacity can be achieved to meet local government standard for wastewater containing $\mathrm{Cr}$ (VI).

This study examined the development of adsorption capacity in relation to the activation mechanism. Activation resulting drastic change on $\mathrm{Cr}$ (VI) adsorption capacity from $44.39 \mathrm{mg} \mathrm{g}^{-1}$ to $532.3 \mathrm{mg} \mathrm{g}^{-1}$ (12:28 ratio). It has to be taken into account that the effect of activation has given a great impact to adsorption capacity.

\section{NOMENCLATURE}

q adsorption capacity

Co initial concentration

$\mathrm{Ct}$ equilibrium concentration

$V \quad$ volume of testing solution

W weight of adsorbent

\section{ACKNOWLEDGMENT}

Authors are indebted to a number of people and organizations who made the direct and indirect contributions to this work. Authors are also thankful to Lembaga Penelitian Universitas Sriwijaya for providing financial support. The authors acknowledge significant experimental support from laboratory staff of Chemical Engineering Department.

\section{REFERENCES}

[1] M. Turan, U. Mart, B. Yuksel, M.S. Celik, Lead removal in fixedbed columns by zeolite and sepiolite, Chemosphere 60, pp. 14871492, 2005.

[2] A. Dimirkou, Uptake of $\mathrm{Zn}^{2+}$ ions by a fully iron-exchanged clinoptilolite, Case study of heavily contaminated drinking water samples, Water Res, vol. 412, pp. 2763-2773, 2007.

[3] M.K. Doula, A. Dimirkou, Use of an iron-over exchanged clinoptilolite for the removal of $\mathrm{Cu}^{2+}$ ions from heavily contaminated drinking water samples, J. Hazard. Mater, vol. 151, pp. 738-745, 2008.

[4] P. Kumar, C. Sung, O. Muraza, M. Cococcioni, S.A. Hashimi, A. McCormick, M. Tsapatsis, $\mathrm{H}_{2} \mathrm{~S}$ adsorption by $\mathrm{Ag}$ and $\mathrm{Cu}$ ion exchanged faujasites, Microporous and Mesoporous Materials, vol. 146, pp. 127-133, 2011.

[5] S. Wang, T. Terdkiatburana, M.O. Tade, Adsorption of $\mathrm{Cu}(\mathrm{II}), \mathrm{Pb}$ (II) and humic acid on natural zeolite tuff in single and binary systems, Separation and Purification Technology, vol. 62, pp. 64-70, 2008.

[6] C.A. Ríos, C.D. Williams, M.A. Fullen, Nucleation and growth history of zeolite LTA synthesized from kaolinite by two different methods, Applied Clay Science, vol. 42, pp. 446 - 454, 2009.

[7] S.C. Larsen Larsen. Nanocrystalline Zeolites and Zeolite Structures: Synthesis, Characterization, and Applications, Journal of Physical Chemistry. C, vol. 111, pp. 18464 - 18474, 2007.

[8] E.M. Flanigen, H.Van Bekkum, J.C. Jansen, Introduction to Zeolite Science and Practice, second ed., Elsevier Science, 2001.

[9] Rusnam, Asmiwarti, Efrizal, and A. Sofyani, The influence of water hyacinth to decrease the heavy metals, International Journal on Advanced Science Engineering Information Technology, Vol.3 (6), pp 10-12, 2013

[10] S.A. Idris, K.M. Alotaibi, T.A. Peshkur, P. Anderson, M. Morris, Adsorption kinetic study: Effect of adsorbent pore size distribution on the rate of $\mathrm{Cr}$ (VI) uptake, Microporous Mesoporous Mater, pp. 99-165, 2013.

[11] N. Fellenz, P. Martin, S. Marchetti, F. Bengoa, Aminopropylmodified mesoporous silica nanospheres for the adsorption of $\mathrm{Cr}(\mathrm{VI})$ from water, Journal of Porous Material, pp. 22-729, 2015.

[12] J, Hu, X. Wang, L. Liu, L.Wu, A facile and general fabrication method for organic silica hollow spheres and their excellent adsorption properties for heavy metal ions, Journal of Materials Chemistry A, vol. 46, pp. 19771-19777, 2014.

[13] M.A. Barakat, Arab, New trends in removing heavy metals from industrial wastewater, Arabian Journal of Chemistry, vol. 4, pp. 361-377, 2011.

[14] W.S.W. Ngah, L.C. Teong, M.A.K.M. Hanafiah, Adsorption of dyes and heavy metal ions by chitosan composites: A review, Science Direct Journal, Carbohydrate Polymers, vol. 83, pp. 1446-1456, 2011.

[15] S. Babel, T.A. Kurniawan, Low-cost adsorbents for heavy metals uptake from contaminated water: a review. Journal of Hazard Material, vol. 97, p. 219, 2013.

[16] B. Dousova, T. Grygar, A. Martaus, L. Fuitova, D. Kolousek, and V. Machovic," Sorption of As(V) on aluminosilicates treated with Fe(II) nanoparticles," J. Colloid. Interface Sci., vol. 302, pp. 424-431, 2006.

[17] A. Zehhaf, A. Benyoucef, C. Quijada, S. Taleb, and E. Morallón, "Algerian natural montmorillonites for arsenic(III) removal in aqueous solution," International Journal of Environmental Science and Technology, vol. 12, pp. 595-602, 2013.

[18] A. Ramesh, H. Hasegawa, T. Maki, and K. Ueda, "Adsorption of inorganic and organic arsenic from aqueous solutions by polymeric $\mathrm{Al} / \mathrm{Fe}$ modified montmorillonite," Separation and Purification Technology, 56, pp. 90-100, 2007.

[19] A. Sdiri, T. Higashi, T. Hatta, F. Jamoussi, and N. Tase, "Evaluating the adsorptive capacity of montmorillonite and calcareous clays on 
the removal of several heavy metals in aqueous systems," Chemical Engineering Journal, vol. 172, pp. 37-46, 2011.

[20] X. Ren, Z. Zhang, H. Luo, B. Hu, Z. Dang, C. Yang, and L. Li, "Adsorption of arsenic on modified montmorillonite," Applied Clay Science, Rep. 97-98, pp. 17-23, 2014

[21] C. Luengo, V. Puccia, and M. Avena, "Arsenate adsorption and desorption kinetics on a Fe(III)-modified montmorillonite," J. Hazard Mater., vol. 186, pp. 1713-1719, 2011.

[22] M.Q. Jiang, Q. P. Wang, X. Y. Jin, and Z. L. Chen, "Removal of $\mathrm{Pb}$ (II) from aqueous solution using modified and unmodified kaolinite clay," Journal of Hazard Material, vol. 170, 332-339, 2009.

[23] D. Mohapatra, D. Mishra, G. R. Chaudhury, and R. P. Das, "Arsenic(V) adsorption mechanism using kaolinite, montmorillonite, and illite from aqueous medium," Journal of Environment Science and Health A Tox Hazard Subst. Environ. Eng., vol. 42, pp. 463-469, 2007.

[24] M. Khashij, S. A. Mousavi, M. Mehralian, M. R. Massoudinejad, Removal of $\mathrm{Fe}^{2+}$ from the Aqueous Solution Using Manganese Oxide Coated Zeolite and Iron Oxide Coated Zeolite, International Journal of Engineering (IJE), TRANSACTIONS B: Applications, Vol. 29 (11), pp 1587-1594, 2016

[25] S.S. Han, D.H. Jung, J. Heo, Interpenetration of Metal Organic Frameworks for Carbon Dioxide Capture and Hydrogen Purification: Good or Bad?, The Journal of Physics Chemistry C, vol. 117, pp. 71 $-77,2013$.

[26] N. S. Indeswari, Identification of Patchouli - chemical properties on oil purification by using acid-activated bentonite, International Journal on Advanced Science Engineering Information Technology, Vol.5 (1), pp 13-15, 2015 